Canadian Studies in Population, Vol. 35.1, 2008, pp. 103-117

\title{
Does It Pay to Migrate? The Canadian Evidence
}

\author{
Y. Edward Shin \\ Bali Ram \\ Demography Division \\ Statistics Canada \\ Ottawa, Canada \\ edward.shin@statcan.ca
}

\begin{abstract}
An analysis of the 1991 and 1996 Census data indicated that on average people who moved out of economically less affluent provinces showed higher incomes than those who were left behind. However, persons who moved out of wealthier provinces did not do as well as those who stayed. In fact, their incomes were lower than non-migrants. According to the 1996 Census, for example, the ageeducation adjusted income of migrants from Ontario, Alberta, and British Columbia was about 10 to $13 \%$ lower than non-migrants in those provinces, whereas the corresponding income was about 7 to $13 \%$ higher for migrants from Atlantic Provinces. Similarly, people who moved into economically less resourceful provinces had higher incomes than non-migrants, while inmigrants into affluent provinces did worse than those who stayed in those provinces.
\end{abstract}

Key Words: In-migrant, out-migrant, migrants' income, census, inter-provincial migration 


\section{Résumé}

Une analyse des données des recensements de 1991 et de 1996 révèle qu'en moyenne, les personnes qui ont quitté les provinces moins prospères avaient des revenus plus élevés que celles qui sont restées. Toutefois, les personnes qui ont quitté les provinces plus riches n'ont pas fait aussi bien que celles qui sont restées. En fait, leurs revenus étaient plus faibles que ceux des non-migrants. Par exemple, selon le Recensement de 1996, le revenu des migrants de l'Ontario, de l'Alberta et de la Colombie-Britannique rajusté selon l'âge et la scolarité était d'environ 10 à $13 \%$ inférieur à celui des non-migrants de ces provinces, tandis que le revenu correspondant des migrants des provinces de l'Atlantique était d'environ 7 à $13 \%$ supérieur. De même, les personnes qui se sont installées dans des provinces moins prospères avaient des revenus plus élevés que ceux des non-migrants, tandis que les personnes qui ont migré vers les provinces mieux nanties s'en sont moins bien tirées que celles qui sont demeurées dans ces provinces.

Mots clés: Entrants, sortants, revenu des migrants, recensement, migration interprovinciale

\section{Introduction}

Do migrants gain economically from moving? The answer to this question is not straightforward. It depends largely on the characteristics of migrants themselves and the characteristics of the regions of their origin and destination. The thesis that migrants gain from moving posits that migrants respond to the regional economic disparity, especially to wage gaps between the place of origin and the place of destination. Thus, migration would be at a minimum in the absence of differences in incomes between regions, but would increase in the direction of the destinations which provide them greater income. The basic assumption underlying this hypothesis is that most people move because they expect an improvement in their economic conditions. In a country such as Canada where regional economic disparity is large, one expects people to move away from regions of weak labour demand to regions of greater labour demand, which offer them the greater net economic gain. Given that migration is selective of the younger, better educated and more productive workers, it is reasonable to argue that people moving from regions with less economic resources to the regions of greater resources, gain more than those who were left behind. 
The story is different when migrations occur from regions with greater economic resources to the regions of less economic resources. It is also different when economy is not doing as well. During these situations, migrants need not be positively selected. People who move to economically less attractive destinations or during bad economic times are likely to be less skilled, and therefore, less likely to earn more than non-migrants.

In this paper, two hypotheses were examined using data from the 1991 and 1996 Censuses. The 1991 Census provides data on income for 1990 and migration during 1986-91 period and the 1996 Census provides data on income for 1995 and migration for 1991-96. These two periods are also reflective of two economic climates: good economic times of the late 1980s and bad economic times for the early 1990 s.

Some economists such as Sjaastad (1962) view migration as human capital investment. When people want to move, they tend to compare costs and benefits of moving. Costs include monetary costs and non-monetary costs. Some examples of the former are moving expense and the increased cost in housing and food. Non-monetary costs may be sometimes more important than monetary cost for some people. For example, searching for a job or learning a new skill and 'psychic cost' such as leaving familiar surroundings, family and friends are very important costs. Despite these costs, people move, when they find benefits are larger. Benefits include higher earnings, better climate, generous government benefits, better school and joining family or friends, to name a few. But many of these are hard to measure.

Because of different sets of costs and benefits to consider, people move for different reasons. A survey of Statistics Canada conducted in 1987 (Current Population Profile) showed that about one third (34\%) of the respondents moved to another province because of job related reasons, such as transfer, acceptance of a new job or looking for a job (Verma and Broad, 1989). Almost half (47\%) of the interprovincial migrants moved to accompany their spouse or parents. There were other reasons for migration: to go to school $(5 \%)$, retirement $(1.3 \%)$, climate/scenery $(2.3 \%)$, etc. In spite of many important non-economic reasons for migration, this study attempts to see whether or not interprovincial migrants gain by migrating, as measured by their total income.

\section{Method, Variables and Data Sources}

The following variables are taken from two Canadian Censuses (1991 and 1996) for interprovincial in- and out-migrants and non-migrants: Average individual total income in 1995 constant dollar; age; education (highest level of education) 
and provinces. Total Income in the census refers to the total money income received from various sources during the year prior to the census, and is the sum of employment income, government transfer payments, investment income and other income for an individual. Standardised income variable was calculated controlling for age and education at the same time. To do this, one standard population was used for every province and each of in-, out- or non-migrant population. The standard population used is the number of Canadian population 15 years old and over by age group and education minus the number of people who lived outside Canada five years prior to census and minus the number of people who did not have any income. The standardised income is obtained by: 1) multiplying average income for each age category of each education category by standard population in the same categories; 2) summing the results of the step 1 ; and 3 ) dividing the sum in step 2 by the sum of all age and education categories in the standard population.

There are some limitations to this data source. Because Census collects the income data for the calendar year just prior to the census, the data are after migration income in many cases. For people who migrated during or after the year for which income is collected, their income is not affected by the migration. No income data before migration are available from the Census. However, because the focus of the study is impact of migration on economic status, the income data after migration is reasonable. Census data on interprovincial migration do not include return migrants. This group of interprovincial migrants is by design included in the non-interprovincial migrants.

\section{Migrants are Positively Selected}

Canadians are one of the mobile people in the world. According to the Canadian Censuses, close to a half of the population changed their residence in any five-year period, showing for example $47 \%$ in the 1986-1991 period and $43 \%$ in the 1991-1996 period. These numbers include those who moved to next door as well as those who migrated across the country from Newfoundland to British Columbia. However, the extent of interprovincial migration is somewhat smaller at $3.9 \%$ or 819,645 people 15 years of age and older in the 1986-1991 period and $3.3 \%$ or 754,585 persons 15 years old and over in the 1991-1996 period.

The number of interprovincial migrants differs from province to province as well. For some provinces, there were more people who migrated in from other provinces than those who migrated out as shown in Table 1 . The volume of migration is large for some provinces and small for others. The numbers change over time as well due to several reasons, such as economic ups and downs or 
changes in political environment. Whatever the reasons are, some people migrate from one province to another, while others move just next door or do not move at all.

The migration rates are different by age groups and education (highest level of education). Literature indicates that younger people are normally prone to migration and that better-educated are more likely to migrate. Canada is no exception. Table 2 reveals higher migration rates for two younger age groups (15-24 and 25-44) for both periods examined. The people in the youngest age group (15-24) were over four times more likely to move to another province than the elderly (65+).

Migration selectivity is also clearly associated with education. For every age group, people with higher education were more likely to move than those with less education. Interestingly, the selectivity by education weakened somewhat during the 1991-1996 period. Compared with the preceding intercensal period, there was an overall decline in the mobility of Canadians during this period, but the pattern was more pronounced among the better educated. Between 19861991 and 1991-1996, when the overall migration rate was reduced by $15 \%$, from 44 per thousand to 37 per thousand, the migration rate among the university educated was reduced by $21 \%$, from 75 per thousand to 60 per thousand. The downturn of the Canadian economy during the early 1990s is a possible explanation of this phenomenon. It is likely that when the economic climate of the country is vibrant, migrants are attracted to regions of affluence and therefore highly positively selected. However during the times of economic stagnation, migration is not necessarily a response of economic attraction and therefore the positive selectivity of migration is less pronounced.

This highly mobile group also has high average income. In the 1986-1991 period, the average income of interprovincial migrants whose level of education is just under nine years was $\$ 17,403$, whereas the income of the interprovincial migrants with university degree was $\$ 41,104$. The situation was quite similar in the 1991-1996 period, showing $\$ 14,855$ and $\$ 37,260$, respectively. With this positive selectivity, it is expected that people who move from one province to another gain more than those who stay. 
Y. Edward Shin and Bali Ram

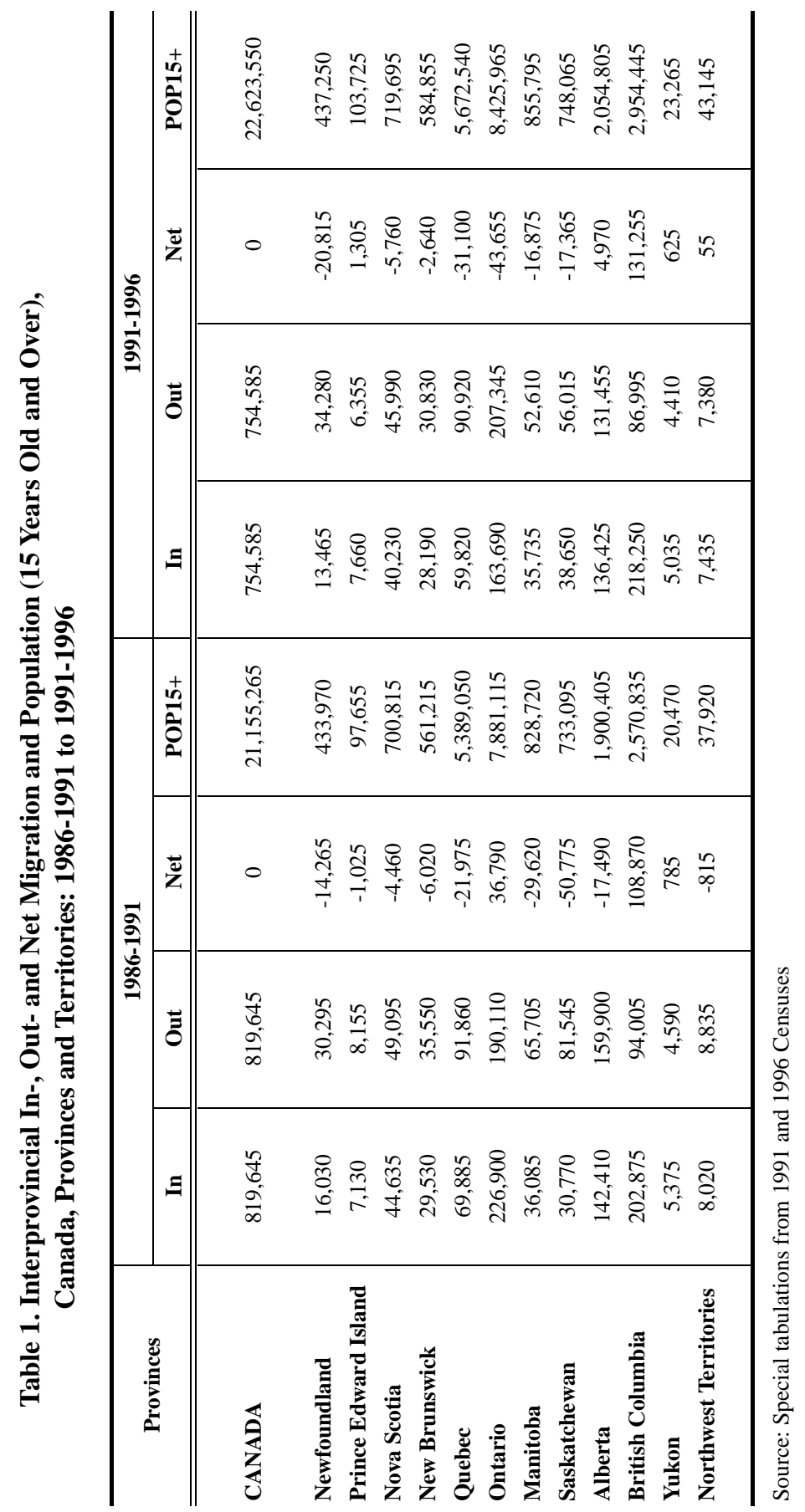


Does It Pay to Migrate? The Canadian Evidence

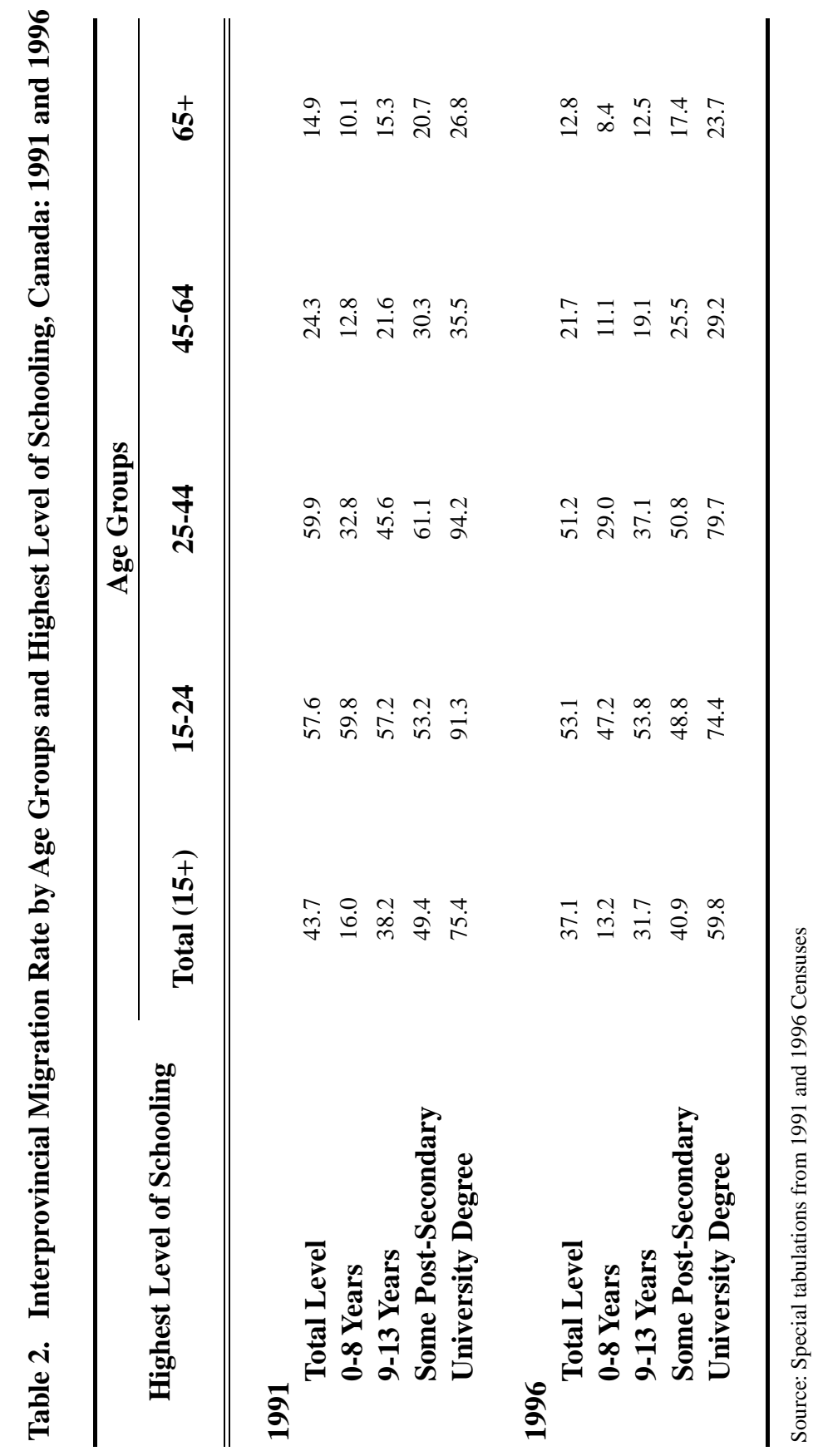




\section{Migrants Gain when They Move Out of Economically Disadvantaged Provinces}

The average total income of migrants is higher than that of non-migrants in most cases, both at the national and the provincial levels. At the national level, migrants' income was higher than non-migrants in the period of 1986-1991, showing \$27,934 and \$27,004, respectively. According to the 1996 Census, however, the income $(\$ 25,139)$ of the interprovincial migrants was lower than that $(\$ 25,470)$ for non-migrants. This decline of income for both groups seems to coincide with the economic downturn during the first half of the 1990s.

At the provincial level, there were nine provinces and territories where the income of out-migrants was higher than that of non-migrants in the 1986-1991 period. The ratios of average income of out-migrants to that of non-migrants indicate that people from all economically disadvantaged provinces gained (Column 1 in Table 3). Out-migrants from the Atlantic provinces gained the most, ranging from $20 \%$ to $26 \%$ more income than the non-migrants. The gains of out-migrants from two prairie provinces, Manitoba and Saskatchewan, were also larger than those of non-migrants of the provinces at $16 \%$ and $14 \%$, respectively. The gains of out-migrants from these provinces were somewhat different depending on where they migrated to. On average, those who moved to wealthier provinces had larger gains than those who moved to economically less resourceful provinces.

In British Columbia and Ontario, the average incomes of out-migrants were lower than that of non-migrants. Strangely, Alberta did not show lower income among out-migrants, but gain was much smaller at only $3 \%$ than those of outmigrants from the Atlantic provinces. The average incomes of out-migrants from these provinces were higher among those who migrated to a wealthier province than among those who moved to a disadvantaged province.

In general, out-migrants from economically disadvantaged provinces seemed to do better than non-migrants of the provinces, but those who move out of an economically wealthier province were not better off than non-migrants of those provinces on the average.

In the 1991-1996 period, the higher income of out-migrants than that of nonmigrants (ratio of above 1) was observed in eight out of 12 provinces and territories (Column 3 of Table 3). Only one difference from the 1991 data was Alberta, which showed a ratio of below one. As one of the economically advantageous provinces, it was expected that out-migrants from Alberta to 
Table 3

Ratio of Average Individual Total Income of Interprovincial Migrants to that of Non-migrants for Canada, Provinces and Territories: 1991 and 1996

\begin{tabular}{|c|c|c|c|c|}
\hline \multirow{3}{*}{$\begin{array}{c}\text { Province and } \\
\text { Territories }\end{array}$} & \multicolumn{4}{|c|}{ Out-migrants to Non-migrants } \\
\hline & \multicolumn{2}{|c|}{1991} & \multicolumn{2}{|c|}{1996} \\
\hline & Unadjusted & $\begin{array}{c}\text { Age-Education } \\
\text { Adjusted }\end{array}$ & Unadjusted & $\begin{array}{l}\text { Age-Education } \\
\text { Adjusted }\end{array}$ \\
\hline CANADA & 1.034 & 0.961 & 0.987 & 0.937 \\
\hline Newfoundland & 1.257 & 1.122 & 1.124 & 1.097 \\
\hline Prince Edward Island & 1.232 & 1.137 & 1.162 & 1.100 \\
\hline Nova Scotia & 1.242 & 1.132 & 1.211 & 1.133 \\
\hline New Brunswick & 1.197 & 1.106 & 1.120 & 1.072 \\
\hline Quebec & 1.178 & 1.040 & 1.147 & 1.009 \\
\hline Ontario & 0.971 & 0.890 & 0.935 & 0.872 \\
\hline Manitoba & 1.158 & 1.047 & 1.097 & 1.025 \\
\hline Saskatchewan & 1.135 & 1.057 & 1.121 & 1.068 \\
\hline Alberta & 1.028 & 0.962 & 0.918 & 0.881 \\
\hline British Columbia & 0.948 & 0.919 & 0.898 & 0.898 \\
\hline Yukon & 0.881 & 0.864 & 0.841 & 0.850 \\
\hline Northwest Territories & 1.149 & 0.839 & 1.030 & 0.787 \\
\hline \multirow{3}{*}{$\begin{array}{c}\text { Province and } \\
\text { Territories }\end{array}$} & \multicolumn{4}{|c|}{ In-migrants to Non-migrants } \\
\hline & \multicolumn{2}{|c|}{1991} & \multicolumn{2}{|c|}{1996} \\
\hline & Unadjusted & $\begin{array}{l}\text { Age-Education } \\
\text { Adjusted }\end{array}$ & Unadjusted & $\begin{array}{l}\text { Age-Education } \\
\text { Adjusted }\end{array}$ \\
\hline CANADA & 1.034 & 0.961 & 0.987 & 0.937 \\
\hline Newfoundland & 1.193 & 1.017 & 1.182 & 0.983 \\
\hline Prince Edward Island & 1.153 & 1.008 & 1.089 & 1.019 \\
\hline Nova Scotia & 1.162 & 1.037 & 1.116 & 1.041 \\
\hline New Brunswick & 1.213 & 1.046 & 1.156 & 1.013 \\
\hline Quebec & 1.182 & 1.055 & 1.080 & 0.986 \\
\hline Ontario & 1.022 & 0.945 & 0.988 & 0.923 \\
\hline Manitoba & 1.104 & 1.029 & 1.052 & 0.999 \\
\hline Saskatchewan & 1.108 & 1.012 & 0.944 & 0.900 \\
\hline Alberta & 0.924 & 0.932 & 0.932 & 0.966 \\
\hline British Columbia & 0.973 & 0.921 & 0.915 & 0.871 \\
\hline Yukon & 1.039 & 1.015 & 0.939 & 0.918 \\
\hline Northwest Territories & 1.455 & 1.025 & 1.316 & 1.029 \\
\hline
\end{tabular}

Source: Special tabulations from 1991 and 1996 Censuses. 
be worse off than people who remained in the province, and it was so in the 1991-1996 period.

Will these observations remain true when the age-education-adjusted incomes were compared?

\section{What Happens when Age and Education is held Constant?}

Higher income of out-migrants from most provinces could have been due to exodus of better-educated people who usually have higher income. This exodus could result in a reduced income for the non-migrants in the province of origin. If the effect of education of migrants on income is eliminated, the ratio of average income of out-migrants to non-migrants is expected to be reduced. In the 1986-1991 period, the ratios based on the age-education-adjusted average income have been reduced among all provinces and territories. However, the average incomes of out-migrants from the Atlantic provinces, Quebec and two prairie provinces were still higher than that of non-migrants. In addition to Ontario, British Columbia and Yukon, ratios for Alberta and Northwest Territories also were reduced to a value of below one, indicating that the outmigrants from these provinces and territories were worse off.

In the 1991-1996 period, the ratios that were based on the age-educationadjusted income were smaller than those from the ratios that were based on the unadjusted income among all areas but British Columbia and Yukon. The increase of the ratios in these two areas can be interpreted as that the outmigrants were negatively selected, i.e., exodus of smaller number of bettereducated people. As in the 1986-1991 period, out-migrants from the economically disadvantaged provinces were better off. Out-migrants from such affluent provinces as Ontario, Alberta and British Columbia did not do better than those who remained in them. The conclusion made based on the unadjusted income data is supported by the data adjusted for age and education.

\section{In-migrants into Economically Disadvantaged Provinces Gain as Well}

The findings for in-migrants were quite similar to those for out-migrants. The average total incomes of in-migrants were higher than that of non-migrants in all provinces and territories but Alberta and British Columbia, according to the unadjusted income data in the 1986-1991 period (Table 3, lower panel). The ratio of the average incomes of in-migrants to that of non-migrants were also the largest for the Atlantic provinces, ranging from $15 \%$ for Prince Edward Island to 
$21 \%$ for New Brunswick above the non-migrants' income. Next come Manitoba and Saskatchewan, showing about $10 \%$ more income among in-migrants than among non-migrants. While in-migrants to Alberta and British Columbia did not do better, in-migrants to Ontario were better off. Courchene (1974) also found from the 1966 incomes that incomes of in-migrants were lower in these three provinces.

During the economic slow period, 1991-1996, in-migrants gained less in five provinces and territories, compared to only two provinces in the 1986-1991 period. The in-migrants to all four Atlantic provinces continued to do better, despite less degree. Surprisingly, in-migrants to Saskatchewan were worse off than non-migrants, whereas Manitoba showed slightly more income among inmigrants than non-migrants.

In a number of provinces and territories, the income of interprovincial inmigrants became lower than that of non-migrants, when the age-educationadjusted income was compared. For example, there were seven provinces and territories that showed higher income among interprovincial in-migrants than among non-migrants in 1996 according to the unadjusted income, but there were only four provinces and territories according to the adjusted income. During the 1991-1996 period, which was coincidentally a period of economic downturn, the average income was not only smaller than 5 years before but also the income gap between migrants and non-migrants seemed to have been reduced as well.

\section{Migrants Moving from Disadvantaged Provinces to Affluent Provinces Gain Most}

Incomes of migrants at the place of destination were compared with the incomes of non-migrants at the place of origin earlier. Obviously, the incomes of nonmigrants of less affluent area are expected to be lower than the incomes of migrants from these provinces who move to more affluent area. Similarly, the incomes of non-migrants of more affluent provinces will be higher than the incomes of migrants from these regions moving to less affluent area. In order to understand this observation more clearly, the ratio of migrants' income to the non-migrants' income were ranked in Table 4 in descending order. Based on the sufficient number of migrants, only 46 pairs of origin-destination were selected for this portrayal. When looking at both periods, it is obvious that people who moved from less affluent provinces in Atlantic and Prairie provinces to Ontario, Alberta and British Columbia gained the most, while those moved in reverse directions lost the most. 


\section{Y. Edward Shin and Bali Ram}

Table 4

Ratio of Age-Education-Adjusted Income of Out-migrants to Income of Non-migrants Selected Origin-Destination, Canad: 1991 and 1996

\begin{tabular}{|c|c|c|c|}
\hline \multicolumn{2}{|c|}{ Descending Order by 1996 Ratio } & \multicolumn{2}{|c|}{ Descending Order by 1991 Ratio } \\
\hline & 1996 & & 1991 \\
\hline Nova Scotia to Alberta & 1.23 & New Brunswick to Ontario & 1.22 \\
\hline New Brunswick to B.C. & 1.19 & Nova Scotia to Ontario & 1.16 \\
\hline Nova Scotia to Ontario & 1.18 & Nova Scotia to Quebec & 1.16 \\
\hline Nova Scotia to B.C. & 1.13 & Saskatchewan to Ontario & 1.13 \\
\hline Newfoundland to Ontario & 1.12 & Newfoundland to B.C. & 1.13 \\
\hline Nova Scotia to Quebec & 1.11 & Nova Scotia to Alberta & 1.12 \\
\hline Manitoba to Ontario & 1.11 & Manitoba to Ontario & 1.12 \\
\hline Saskatchewan to Alberta & 1.10 & Nova Scotia to B.C. & 1.11 \\
\hline Manitoba to Alberta & 1.10 & Newfoundland to Ontario & 1.10 \\
\hline New Brunswick to Ontario & 1.09 & Newfoundland to Alberta & 1.10 \\
\hline Saskatchewan to Ontario & 1.08 & Quebec to Ontario & 1.08 \\
\hline Manitoba to Quebec & 1.08 & Saskatchewan to Alberta & 1.05 \\
\hline New Brunswick to Alberta & 1.06 & New Brunswick to Alberta & 1.05 \\
\hline Newfoundland to Alberta & 1.05 & Alberta to Ontario & 1.05 \\
\hline Quebec to Ontario & 1.05 & New Brunswick to Quebec & 1.04 \\
\hline Quebec to Alberta & 1.05 & Manitoba to Alberta & 1.03 \\
\hline Newfoundland to B.C. & 1.02 & Nova Scotia to New Brunswick & 1.03 \\
\hline Nova Scotia to New Brunswick & 1.02 & Nefoundland to Nova Scotia & 1.03 \\
\hline Nefoundland to Nova Scotia & 1.01 & Saskatchewan to B.C. & 1.03 \\
\hline Saskatchewan to B.C. & 1.01 & Quebec to Nova Scotia & 1.02 \\
\hline New Brunswick to Nova Scotia & 1.01 & New Brunswick to Nova Scotia & 1.01 \\
\hline Alberta to Ontario & 0.99 & New Brunswick to B.C. & 1.00 \\
\hline Saskatchewan to Manitoba & 0.99 & Saskatchewan to Manitoba & 1.00 \\
\hline Manitoba to Saskatchewan & 0.96 & B.C. to Ontario & 1.00 \\
\hline Quebec to Nova Scotia & 0.95 & Manitoba to Quebec & 0.99 \\
\hline Manitoba to B.C. & 0.95 & Manitoba to B.C. & 0.99 \\
\hline New Brunswick to Quebec & 0.93 & Quebec to Alberta & 0.96 \\
\hline B.C. to Ontario & 0.93 & Onario to Quebec & 0.95 \\
\hline Ontario to Alberta & 0.93 & Quebec to B.C. & 0.95 \\
\hline B.C. to Alberta & 0.93 & Manitoba to Saskatchewan & 0.94 \\
\hline Ontario to Manitoba & 0.92 & Alberta to Quebec & 0.92 \\
\hline Alberta to Quebec & 0.90 & Alberta to B.C. & 0.92 \\
\hline Quebec to New Brunswick & 0.89 & Alberta to Saskatchewan & 0.92 \\
\hline Ontario to Saskatchewan & 0.88 & Ontario to Alberta & 0.91 \\
\hline Onario to Quebec & 0.87 & Ontario to Manitoba & 0.91 \\
\hline Ontario to B.C. & 0.87 & Alberta to Manitoba & 0.91 \\
\hline Alberta to B.C. & 0.86 & Quebec to New Brunswick & 0.89 \\
\hline Quebec to B.C. & 0.85 & B.C. to Alberta & 0.88 \\
\hline Alberta to Manitoba & 0.84 & Ontario to B.C. & 0.88 \\
\hline Ontario to Nova Scotia & 0.83 & Ontario to Saskatchewan & 0.84 \\
\hline Ontario to New Brunswick & 0.81 & Ontario to Nova Scotia & 0.83 \\
\hline Alberta to Saskatchewan & 0.77 & Ontario to New Brunswick & 0.83 \\
\hline B.C. to Quebec & 0.77 & B.C. to Quebec & 0.83 \\
\hline B.C. to Manitoba & 0.75 & B.C. to Saskatchewan & 0.82 \\
\hline B.C. to Saskatchewan & 0.74 & B.C. to Manitoba & 0.81 \\
\hline Ontario to Newfoundland & 0.72 & Ontario to Newfoundland & 0.75 \\
\hline
\end{tabular}

CSP 2008, 35.1: 103-117 
During 1986-1991 period, the largest gains were made by migrants who moved from New Brunswick to Ontario (22\%), followed by those who moved from Nova Scotia to either Ontario (16\%) or Quebec (16\%). Almost all migrants who gained more than $5 \%$ were those who moved from the Atlantic provinces to wealthier provinces, such as Ontario, Quebec, British Columbia and Alberta. Conversely, migrants who moved into less affluent provinces did not do better even if they were from affluent provinces. During the 1991-1996 period, the top three gainers were migrants from Nova Scotia to Alberta (23\%), from New Brunswick to British Columbia (19\%), and from Nova Scotia to Ontario (18\%). During both periods, migrants from Ontario to Newfoundland, and those from British Columbia to Quebec, Manitoba, and Saskatchewan were most to lose.

It was also not much advantageous to move within the regions of similar economic-industrial climates. Migrants who moved within the Atlantic Provinces or those within the Prairies, gained almost the same as those who did not move. During both 1986-91 and 1991-96, migrants from Ontario to Alberta and British Columbia, those from British Columbia to Ontario and Alberta, and those from Alberta to British Columbia had lower incomes than those left behind.

\section{Conclusion}

In a large country such as Canada, a small portion of the population move from one province to another, between $3 \%$ and $5 \%$ over the last 10 year period. People might have moved for different reasons, but many interprovincial migrants might want to gain by migrating. Unadjusted income data of the migrants showed that migrants' income was higher than non-migrants' income in many provinces. This was true especially for the economically disadvantaged provinces. When the income was adjusted for age and education, there were a fewer number of provinces where the migrants' income was higher than nonmigrants. However, the conclusion remains the same.

There were provincial variations in the income differences between migrants and non-migrants. People who moved in to an economically affluent province revealed lower income than that of non-migrants of the province. And persons who moved in to a less wealthy province did better. A few affluent provinces such as Ontario, Alberta and British Columbia were the main destination of the migrants, even though they did not do better than the people in the province.

If this condition continues, the regional or provincial disparities might be reduced. However, the comparison of the incomes of in-migrants and outmigrants of the provinces made this statement somewhat inconclusive. Among 
the wealthier provinces, Alberta and British Columbia showed often that the incomes of in-migrants were higher than that of out-migrants, making the disparity larger. Conversely, the average incomes of out-migrants from the less wealthy provinces were higher than that of in-migrants, resulting in larger gap between these provinces and wealthier provinces.

The level of average income for both interprovincial migrants and non-migrants decreased from 1991 to 1996. During the period of economic downturn in the early 1990s, the average incomes of both groups were reduced. Despite this reduction, there were still more provinces where the incomes of migrants were higher than non-migrants. These were the economically less advantaged provinces.

In almost all provinces and territories, migrants were more likely to be persons with high education and high income. It is indicated by the fact that the ratios of incomes between migrants and non-migrants from the age-education-adjusted

income were reduced compared to the ratio based on the unadjusted income data for almost every area.

\section{Acknowledgement:}

Paper presented at the 2001 meetings of Canadian Population Society, Congress of the Social Sciences and Humanities, Quebec City, May 27-29, 2001. The views expressed in this paper are those of the authors and should not be interpreted as reflecting those of Statistics Canada.

\section{References:}

Courchene, Thomas J. 1974, Migration, Income and Employment: Canada, 1965068, C.D. Howe Research Institute.

Sjaastadt, Larry M. 1962, "The costs and returns of human migration," Journal of Political Economy, 70 (5, part 2): 80-93.

Verma, R. B. P. and D. Broad. 1989, Motivational Factors in Interprovincial Migration: An Analysis of 1987 Current Population Profile Survey. Paper for presentation to the annual meeting of the Canadian Population Society (CPS), Laval University, Québec City, Quebec, June 5-7. 


\section{Appendix}

Unadjusted and Age-Education Adjusted Average Individual Total Income of Non-migrants and Interprovincial In- and Out-migrants for Canada, Provinces and Territories: 1991 and 1996

(in 1995 constant dollar)

\begin{tabular}{|c|c|c|c|c|c|c|}
\hline \multirow{3}{*}{ Province and Territories } & \multicolumn{6}{|c|}{ Unadjusted } \\
\hline & \multicolumn{3}{|c|}{1991} & \multicolumn{3}{|c|}{1996} \\
\hline & Non-migrants & In-migrants & Out-migrants & Non-migrants & In-migrants & Out-migrants \\
\hline CANADA & 27044 & 27934 & 27934 & 25470 & 25139 & 25139 \\
\hline Newfoundland & 20742 & 24749 & 26077 & 19533 & 23081 & 21955 \\
\hline Prince Edward Island & 21140 & 24365 & 26051 & 20397 & 22204 & 23695 \\
\hline Nova Scotia & 23036 & 26767 & 28616 & 21404 & 23889 & 25917 \\
\hline New Brunswick & 21879 & 26541 & 26191 & 20585 & 23806 & 23064 \\
\hline Quebec & 25137 & 29718 & 29616 & 23332 & 25194 & 26766 \\
\hline Ontario & 29654 & 30303 & 28781 & 27723 & 27396 & 25911 \\
\hline Manitoba & 23681 & 26134 & 27413 & 22753 & 23939 & 24964 \\
\hline Saskatchewan & 22975 & 25452 & 26086 & 22648 & 21390 & 25383 \\
\hline Alberta & 27701 & 25605 & 28466 & 26496 & 24694 & 24316 \\
\hline British Columbia & 28045 & 27290 & 26573 & 27048 & 24762 & 24236 \\
\hline Yukon & 29836 & 31001 & 26296 & 29632 & 27830 & 24927 \\
\hline Northwest Territories & 26529 & 38589 & 30481 & 27434 & 36095 & 28263 \\
\hline \multirow{3}{*}{ Province and Territories } & \multicolumn{6}{|c|}{ Age-Education Adjusted } \\
\hline & \multicolumn{3}{|c|}{1991} & \multicolumn{3}{|c|}{1996} \\
\hline & Non-migrants & In-migrants & Out-migrants & Non-migrants & In-migrants & Out-migrants \\
\hline CANADA & 28440 & 27324 & 27324 & 25522 & 23915 & 23915 \\
\hline Newfoundland & 24524 & 24952 & 27519 & 21346 & 20978 & 23413 \\
\hline Prince Edward Island & 23753 & 23954 & 27018 & 21469 & 21883 & 23615 \\
\hline Nova Scotia & 24757 & 25671 & 28029 & 21735 & 22629 & 24623 \\
\hline New Brunswick & 24647 & 25779 & 27254 & 21888 & 22181 & 23455 \\
\hline Quebec & 26918 & 28388 & 28004 & 23803 & 23464 & 24006 \\
\hline Ontario & 30786 & 29097 & 27390 & 27312 & 25213 & 23811 \\
\hline Manitoba & 25592 & 26329 & 26788 & 23528 & 23504 & 24121 \\
\hline Saskatchewan & 25114 & 25417 & 26554 & 23861 & 21473 & 25472 \\
\hline Alberta & 28552 & 26596 & 27479 & 26249 & 25348 & 23124 \\
\hline British Columbia & 28747 & 26466 & 26425 & 26554 & 23115 & 23848 \\
\hline Yukon & 29573 & 30026 & 25553 & 28234 & 25931 & 24010 \\
\hline Northwest Territories & 34383 & 35227 & 28860 & 31983 & 32915 & 25158 \\
\hline
\end{tabular}

Source: Special tabulations from 1991 and 1996 Censuses. 